\title{
PCR-based specific techniques used for detecting the most important pathogens on strawberry: a systematic review
}

Seyed Mahyar Mirmajlessi ${ }^{1 *}$, Marialaura Destefanis ${ }^{2}$, Richard Alexander Gottsberger $^{3}$, Marika Mänd ${ }^{4}$ and Evelin Loit ${ }^{1}$

\begin{abstract}
Background: Strawberry diseases are a major limiting factor that severely impact plant agronomic performance. Regarding limitations of traditional techniques for detection of pathogens, researchers have developed specific DNA-based tests as sensitive and specific techniques. The aim of this review is to provide an overview of polymerase chain reaction (PCR)-based methods used for detection or quantification of the most widespread strawberry pathogens, such as Fusarium oxysporum f.sp. fragariae, Phytophthora fragariae, Colletotrichum acutatum, Verticillium dahliae, Botrytis cinerea, Macrophomina phaseolina, and Xanthomonas fragariae. An updated and detailed list of published PCR protocols is presented and discussed, aimed at facilitating access to information that could be particularly useful for diagnostic laboratories in order to develop a rapid, cost-effective, and reliable monitoring technique.
\end{abstract}

Methods: The study design was a systematic review of PCR-based techniques used for detection and quantification of strawberry pathogens. Using appropriate subject headings, AGRICOLA, AGRIS, BASE, Biological Abstracts, CAB Abstracts, Google Scholar, Scopus, Web of Knowledge, and SpringerLink databases were searched from their inception up to April 2014. Two assessors independently reviewed the titles, abstracts, and full articles of all identified citations. Selected articles were included if one of the mentioned strawberry pathogens was investigated based on PCR methods, and a summary of pre-analytical requirements for PCR was provided.

Results: A total of 259 titles and abstracts were reviewed, of which 22 full texts met all the inclusion criteria. Our systematic review identified ten different protocols for $X$. fragariae, eight for $P$. fragariae, four for $B$. cinerea, six for $C$. acutatum, three for $V$. dahlia, and only one for F. oxysporum. The accuracy and sensitivity of PCR diagnostic methods is the focus of most studies included in this review. However, a large proportion of errors in laboratories occur in the pre-analytical phase of the testing process. Due to heterogeneity, results could not be meta-analyzed.

Conclusions: From a systematic review of the currently available published literature, effective detection assays to detect the major strawberry pathogens have been developed. These assays can function as a basis for clinical labs, regulatory personnel, and other diagnosticians to adapt or implement for detection of these six important strawberry pathogens.

Keywords: Molecular diagnostic methods, PCR-based techniques, Strawberry pathogen detection, Systematic review

\footnotetext{
* Correspondence: m.mirmajlessi@gmail.com

'Department of Field Crops and Grassland Husbandry, Institute of

Agricultural and Environmental Sciences, Estonian University of Life Sciences,

Tartu, Estonia

Full list of author information is available at the end of the article
}

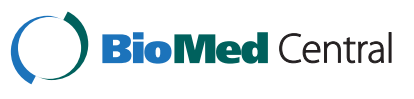

(c) 2015 Mirmajlessi et al.; licensee BioMed Central. This is an Open Access article distributed under the terms of the Creative Commons Attribution License (http://creativecommons.org/licenses/by/4.0), which permits unrestricted use, distribution, and reproduction in any medium, provided the original work is properly credited. The Creative Commons Public Domain Dedication waiver (http://creativecommons.org/publicdomain/zero/1.0/) applies to the data made available in this article, unless otherwise stated. 


\section{Background}

Strawberry (Fragaria $\times$ ananassa) is one of the world's most commercially important fruit crops [1]. It was estimated that the global strawberry production in 2012 was 4,516,810 tons, according to Food and Agriculture Organization (FAO) statistics [2]. Strawberry diseases are a major limiting factor that severely impact the plant agronomic performance and lead to economic losses. Moreover, most strawberry cultivars are highly susceptible to several destructive and economically important pathogenic fungi and bacteria such as Fusarium oxysporum f.sp. fragariae, Phytophthora fragariae, Colletotrichum acutatum, Verticillium dahliae, Botrytis cinerea, Macrophomina phaseolina, and Xanthomonas fragariae $[3,4]$.

Early, rapid, and specific detection and identification of plant pathogens is essential for effective plant disease management [5]. Without specific disease diagnosis, proper control measures cannot be used at the appropriate time [6]. Conventional methods to detect and identify pathogens have often relied on isolating the pathogen onto selective media or through biochemical, chemical, and immunological analyses [7]. These methods are fundamental to diagnose the presence of plant pathogens, but they rely on time-consuming and labor-intensive lab techniques and on skilled taxonomical expertise [8]. Molecular-based techniques can overcome many of the shortcomings of the conventional assays, especially if they rely on polymerase chain reaction (PCR) assays. PCR-based assays are generally more specific and much faster than conventional techniques [5,9]. Moreover, these techniques can also be applied on non-culturable microorganisms, as the organism does not need to be isolated to be identified by PCR [10]. An increasing amount of diagnostic methods recommended by the European and Mediterranean Plant Protection Organization (EPPO) are based on PCR assays $[11,12]$. This technique is nowadays considered a routine technique in molecular diagnosis.

Plant disease management necessitates the need to reduce the spread of the pathogen. The extent in the optimum implementation of control strategies depends not only on the presence of a pathogen but also on the pathogen inoculum load. Thus, the capability of quantifying the pathogen load represents an important aspect of plant disease management [13]. Quantification based on culturing techniques is considered relatively nonspecific, while quantification using PCR techniques, in particular real-time PCR (rtPCR), provides a reliable estimation of the pathogen load. Unlike end-point PCRs, rtPCRs allow the detection of amplification products while the reaction is taking place, i.e., during each PCR cycle. Template quantification is highly specific because it assesses during the exponential phase of the reaction $[9,14]$. Nowadays, a wide range of plant pathogens can be detected and quantified by PCR-based methods in numerous hosts or environmental samples [11,15].

The necessity of fast, sensitive, and specific methods to detect pathogen is important to improve decision making in disease control. So, the primary objective of this review is to provide an exhaustive overview of the existing scientific literature available on PCR-based diagnostic techniques that is restricted to the detection and quantification of the seven most abundant strawberry pathogens: $F$. oxysporum f.sp. fragariae, $P$. fragariae, $C$. acutatum, $V$. dahliae, B. cinerea, $M$. phaseolina, and $X$. fragariae. A secondary objective is to determine the preanalytical requirements of PCR assays (such as sample preparation of target pathogens and treatments prior to amplification). Finally, this compilation intends to provide an updated list of published PCR protocols for detection and quantification of strawberry pathogens with the aim of establishing a common diagnostic PCR basedmethod for routine testing by looking at the factors that affect the efficiency of the different test formats and comparing their performance in pathogen detection in plant material and soil.

\section{Methods}

\section{Search strategy}

In line with our experimental design, only relevant scientific papers published any time before 1 April 2014 and in the English language in a peer-reviewed journal were taken into consideration. The search was extended to libraries, such as AGRICOLA, AGRIS, BASE, Biological Abstracts, CAB Abstracts, Google Scholar, Scopus, Web of Knowledge, Science Direct, and SpringerLink, using the following identifiers: "PCR", "molecular diagnostic", " $F$. oxysporum f.sp. fragariae", "P. fragaria", "C. acutatum", "V. dahliae", "B. cinerea", "M. phaseolina", and "X. fragariae". All associated terms were combined using "OR" and then "AND" to yield a total number of abstracts for each database (see Additional file 1). Two assessors (SMM, EL) independently reviewed the titles and abstracts of all identified citations. Results were limited to strawberry pathogens. Searches were carried out in all fields by default, and, where possible, searches were not restricted to titles or abstracts, but extended to the full text of the article. Both reviewers independently evaluated each full-text article. Disagreements were resolved by consensus. Table 1 lists all selected references that were included in the systematic review.

\section{Selection criteria and data extraction}

Titles and abstracts of papers detected using the search strategy described above were further examined in order to include only articles that investigate molecular diagnostic methods on strawberry pathogens. Thereafter, the articles were further selected if (1) the methods reported 
Table 1 Studies included in the systematic review of PCR techniques used for detecting of strawberry pathogens

\begin{tabular}{|c|c|c|c|c|c|c|}
\hline Year & First author & Pathogen & PCR method & $\begin{array}{l}\text { Sample preparation } \\
\text { (long-term storage) }\end{array}$ & Origin of culture & Reference \\
\hline 1996 & Sreenivasaprasad & CA & Conventional & NG & UK & [73] \\
\hline 1996 & Roberts & XF & Conventional + nested & $-70^{\circ} \mathrm{C}$ in $15 \%$ glycerol & US & {$[49]$} \\
\hline 1996 & Pooler & $X F$ & Multiplex & NG & US & {$[47]$} \\
\hline 1997 & Bonants & PF & Nested & $\begin{array}{c}\text { V8 oatmeal agar containing } \\
50 \text { ppm vancomycin/French } \\
\text { bean agar at } 4^{\circ} \mathrm{C}\end{array}$ & Scotland + Netherlands & [45] \\
\hline 1997 & Mahuku & $X F$ & Nested & $-70^{\circ} \mathrm{C}$ in $25 \%$ glycerol & Canada & {$[50]$} \\
\hline 1997 & Zhang & $X F$ & Conventional & NG & US & {$[74]$} \\
\hline 2002 & Rigotti & $B C$ & $\begin{array}{c}\text { Conventional (Southern blot } \\
\text { hybridization) }\end{array}$ & NG & Switzerland & [22] \\
\hline 2004 & Stöger & XF & Conventional & NG & Austria & [16] \\
\hline 2004 & Zimmermann & $X F$ & Nested & $-20^{\circ} \mathrm{C}$ in $30 \%$ glycerol & Germany & {$[48]$} \\
\hline 2004 & Bonants & PF & $\begin{array}{c}\text { Nested + real-time (TaqMan, Mol. } \\
\text { Beacon) + PCR-ELISA }\end{array}$ & V8 agar at $11^{\circ} \mathrm{C}$ & Netherlands & [13] \\
\hline 2005 & Suarez & $B C$ & Real-time (TaqMan) & Frozen plastic bag at $-20^{\circ} \mathrm{C}$ & UK & [21] \\
\hline 2006 & loos & PF & Conventional & NG & France & [19] \\
\hline 2006 & Drenth & PF & Conventional & Freeze-dried at $-70^{\circ} \mathrm{C}$ & Australia & [72] \\
\hline 2007 & Weller & XF & Real-time (TaqMan) & NG & UK & {$[51]$} \\
\hline 2008 & Vandroemme & XF & Real-time (TaqMan) & NG & Belgium & [18] \\
\hline 2008 & Turechek & $X F$ & Real-time (TaqMan) & NG & US & {$[17]$} \\
\hline 2008 & Pérez-Hernández & CA & Nested + conventional & NG & US & [29] \\
\hline 2008 & Kuchta & VD & Conventional & Czapek-Dox Agar at $4^{\circ} \mathrm{C}$ & Poland & [46] \\
\hline 2009 & Debode & CA & Real-time (TaqMan) & NG & Belgium & {$[27]$} \\
\hline 2009 & Garrido & CA & Conventional + real-time (TaqMan) & Sterile water at $4^{\circ} \mathrm{C}$ & Spain + UK & {$[28]$} \\
\hline 2012 & Bilodeau & VD & Multiplexed real-time (TaqMan) & NG & US & {$[33]$} \\
\hline 2013 & Suga & $\mathrm{FO}$ & Multiplex & $-80^{\circ} \mathrm{C}$ in $50 \%$ glycerol & Japan & [1] \\
\hline
\end{tabular}

XF Xanthomonas fragariae, PF Phytophthora fragariae, BC Botrytis cinerea, VD Verticillium dahliae, FO Fusarium oxysporum, CA Colletotrichum acutatum, NG not given.

a summary of pre-analytical requirements for PCR and (2) the investigation included PCR methods applied on either of the following pathogens: $X$. fragariae, $P$. fragariae, M. phaseolina, F. oxysporum, $V$. dahliae, B. cinerea, and $C$. acutatum. Studies that described PCR-based diagnostic methods but did not investigate strawberry pathogens were excluded from the systematic review.

In addition to this, all references of the selected articles were scanned if the title of the article mentioned the use of molecular diagnostic methods on strawberry pathogens. The newly selected article underwent the same selection criteria outlined above. Four experts on the subject were identified from relevant publications and were contacted by email in order to receive advice on relevant literature on the molecular diagnostic methods in strawberry pathogens. Two responses were received. These included three articles, one was considered not relevant (based on the criteria outlined above) and the remaining two articles had been already identified in the preliminary search. Gray literature (conference abstracts and unpublished studies) and duplicate publications of the same data were disregarded.

\section{Study design and quality}

The full text of all selected articles was read, and relevant information was extracted, summarized, and schematically outlined in tables. All methods described in the included articles were summarized in six tables (see supplemental information: Additional file 2: Tables S1, S2, S3, S4, S5, and S6) based on the aforementioned pathogens. They were referred to in the text by number $(S \#)$. Moreover, each method included in the supplementary tables was assessed for quality on the basis of three criteria that were defined a priori as essential to answer the research questions: used PCR-based methods for detection and quantification of important pathogens on strawberry and soil samples, compared available methods through detection sensitivity and specificity of each method, and presented pre-analytical requirements (i.e., sample preparation) related to the accuracy of each 
method. Studies were defined satisfactory if they met all three criteria.

\section{Data analyses}

The Results section focuses on important strawberry pathogens found in this review. The molecular methods used and main outcomes in each study were investigated. However, a statistical meta-analysis was not justified because of the heterogeneity of the included studies in detecting strawberry pathogens based on PCR-based assays. We synthesized the results (in the supplementary tables) according to PCR protocol, primer sets and target DNA employed in each study, pathogen treatment, and sensitivity of detection.

\section{Results}

The articles originated from 1996 to 2013, with a rapid increase in the number of publications on the topic since 2004. The original systematic search strategy identified 259 unique citations, of which 200 articles were excluded based on the content of the title and/or abstract (Figure 1).

The initial search resulted in 259 hits. Fifty-nine were selected based on the title and abstract. Full text was read and references were checked for additional hits. This resulted in ten additional hits. Twenty-two papers were included based on the full text.

Fifty-nine articles were read and evaluated for inclusion criteria. This resulted in the inclusion of 20 articles.

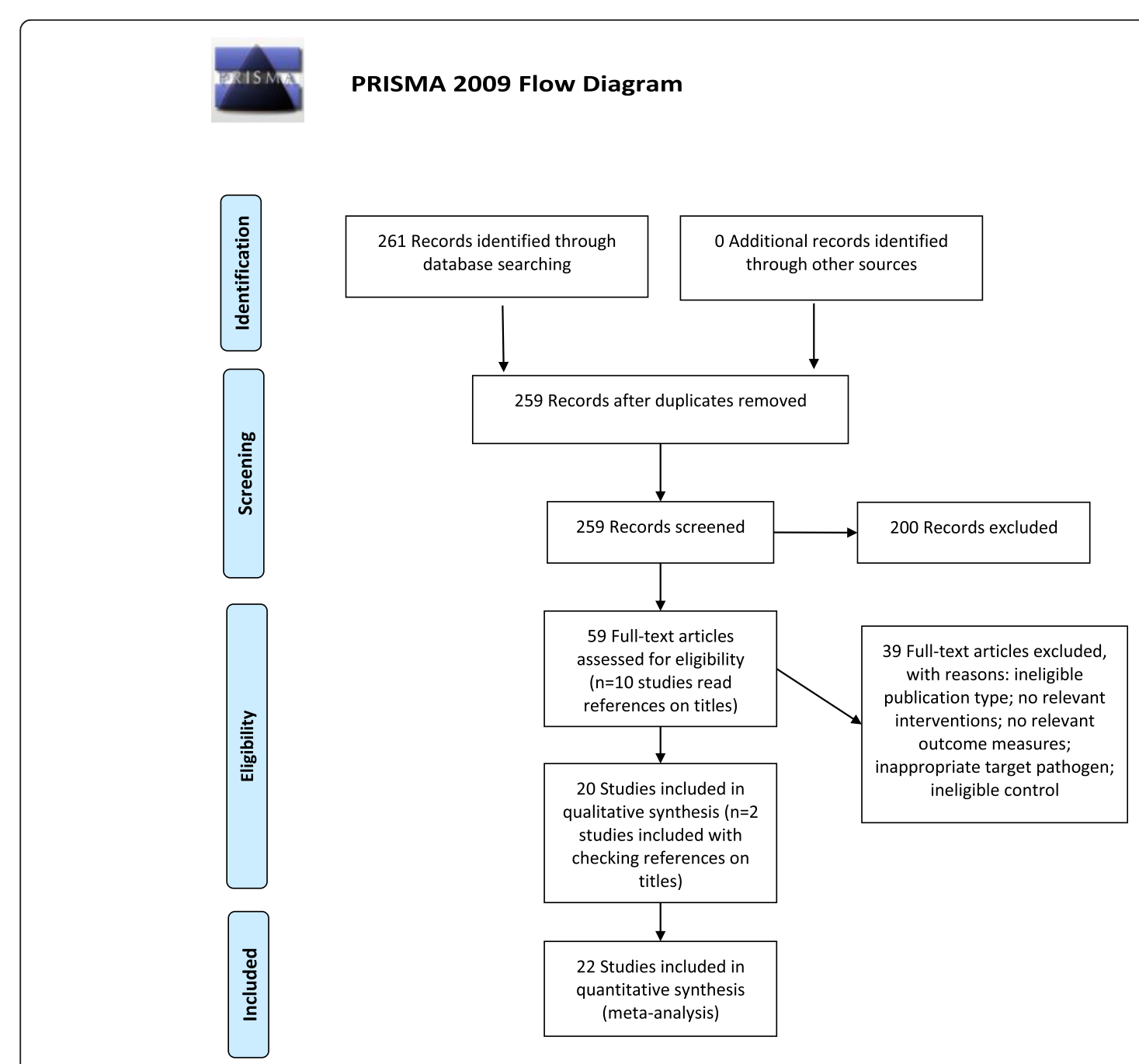

From: Moher D, Liberati A, Tetzlaff J, Altman DG, The PRISMA Group (2009). Preferred Reporting /tems for Systematic Reviews and MetaAnalyses: The PRISMA Statement. PLoS Med 6(6): e1000097. doi:10.1371/journal.pmed1000097

For more information, visit www.prisma-statement.org.

Figure 1 Flow diagram of the study selection process for the systematic review. 
Ten articles were read based on references, of which two were included, bringing the sum of included relevant articles to 22 (Table 1). Several PCR-based techniques were investigated in the 22 selected articles: Nested PCR (nPCR) was investigated in six studies, real-time PCR (rtPCR) was adopted in 12 articles, conventional PCR (cPCR) was reported in ten articles, and four studies focused with other techniques.

The findings are reported as essential data in Table 1 as well as Additional file 2: Tables S1 to S6, which comprised the following information: name of the pathogen in the original article, name of the primer(s) and target DNA, variants utilized in the PCR protocol, type of sample, and treatment prior to amplification, and summarized below according to each pathogen.

\section{Xanthomonas fragariae}

The bacterium $X$. fragariae Kennedy et King (Additional file 2: Table S1), the causal agent of angular leaf spot, is a pathogen that spreads in all major areas of strawberry cultivation [16]. It is a very slow-growing bacterium in culture and is easily overgrown by saprophytic bacteria; selective media are not yet available. Therefore, isolation plating is not recommended for the detection of low $X$. fragariae numbers in symptomless plants [11]. Several PCR detection methods each targeting different loci in the $X$. fragariae genome have been developed. Conventional PCR using species-specific primers is known to differentiate close species and used for detection of $X$. fragariae $[S \# 1,5,6]$. Nested PCR $[S \# 2,4,7]$ is also another main technique used for $X$. fragariae, while multiplex PCR (mPCR) [S\#3] is found just in one study for detection of $X$. fragariae in plant tissue. Notably, rtPCR assays are used for many bacteria including the species on which we focused in this review, although TaqMan chemistry is prominently used for detection and quantification of $X$. fragariae [S\#8-10] that could even detect ten bacterial cells in strawberry crown tissue. The detection of $X$. fragariae in crown tissue extract was possible with real-time PCR but not with standard PCR, which is a significant improvement over standard PCR [17]. The assay offers a new tool for epidemiological research and for sanitary control of plant material with low level or latent infections of pathogen [18].

\section{Phytophthora fragariae}

Conventional PCR [S\#16-18] assays have been developed for P. fragariae (Additional file 2: Table S2) targeting different single-copy genes and rDNA spacer region, although studies show contradicting results on detection sensitivity. In this respect, species-specific polymorphisms were exploited in $R A S$-like and TRP1 genes to develop a set of two $P$. fragariae-specific PCR primer pairs [19]. Thus, it seems to be equally or even more sensitive than other published single-round PCR tests. Real-time PCR and nested rtPCR (nrtPCR) methods using fluorescentlabeled probes $\left(\right.$ TaqMan $^{\mathrm{Tm}}$ and Molecular Beacon ${ }^{\mathrm{TM}}$ ) have the necessary properties to fulfill the requirements of an effective detection system and are the other studied procedures for P. fragariae diagnostic [S\#13-15]. The nested PCR-based method is described to be 1,000-10,000 times more sensitive compared to single-round PCR [13]. With Molecular Beacon ${ }^{\mathrm{TM}}$ probes, the pathogen is detected in a quantitative order similarly to $\operatorname{TaqMan}^{\mathrm{TM}}$ probes, which are able to detect $0.1 \mathrm{fg}$ DNA of the pathogen. In a comparative study, the sensitivity of Molecular Beacon ${ }^{\text {тм }}$ and $\operatorname{TaqMan}^{\mathrm{TM}}$ probes against a dilution series of $P$. fragariae genomic DNA was equivalent [13]. Nested PCR is also reported to successfully detect $P$. fragariae [S\#11] in naturally infected strawberry tissues. Another less investigated test, like PCR-ELISA [S\#12], has been advised for use in pathogen detection. However, this test cannot be recommended for critical diagnosis, since the sensitivity is comparable to gel electrophoresis and ethidium bromide gel staining [13].

\section{Botrytis cinerea}

B. cinerea Pers. Fr. (Additional file 2: Table S3), the causal agent of gray mold or Botrytis blight, establishes symptomless infections, where the pathogen remains latent until the strawberry ripens [20]. TaqMan chemistry [S\#20-22] based on primers and probes designed to the $b$-tubulin gene, the intergenic spacer (IGS) region of the rDNA, and the species-specific sequence-characterized amplified region (SCAR) as the main genomic regions used to design rtPCR assay was applied for the detection and quantification of the fungus in infected strawberry plant tissue before and after symptom expression [20]. Based on Suarez et al. [21] results, the IGS assay gave a $C_{\mathrm{t}}$ value $<40$ of pure $B$. cinerea DNA that was 100 times more sensitive than the SCAR assay and 1,000 times more sensitive than the $b$-tubulin assay. Random amplified polymorphic DNA (RAPD) with Southern blot hybridization [S\#19] is also an applicable and powerful tool for diagnosis of $B$. cinerea in symptomless strawberry under field conditions [22]. In other words, hybridization of southern blots with RAPD and EcoRIdigested DNA confirmed the specificity of the marker for detection and quantification of the pathogen during the latency period. The procedure was able to amplify the $0.7-\mathrm{kb} B$. cinerea fragment from mixed samples of DNA as low as $2 \mathrm{pg}$ B. cinerea genomic DNA and $1 \mu \mathrm{g}$ plant DNA.

\section{Fusarium oxysporum}

F. oxysporum f.sp. fragariae Winks \& Y.N. Williams (Additional file 2: Table S4) is a polyphagous soilborne facultative pathogen causing strawberry wilt disease that 
has dramatically decreased the commercial production of strawberry [23]. Multiplex PCR [S\#23] was used as the main detection technique to determine the pathogen based on DNA fragments. Although MPCR is becoming a rapid and convenient screening assay for most Fusarium spp., it has been used for detection of F. oxysporum in strawberry in just one study. Suga et al. [1] characterized and used some transposable elements (sequencecharacterized amplified regions) in the pathogen to design a specific set of PCR primers, as shown in Additional file 2: Table S4. The genomic region between Han and Skippy (as transposable elements) was amplified by an inter-retrotransposon-amplified polymorphism technique (IRAP-PCR), and specific primers were designed from this region. The developed PCR primers discriminated F. oxysporum f.sp. fragariae strains from nonpathogenic $F$. oxysporum strains and five other formae speciales [1]. Use of other PCR-based techniques could not be found for strawberry fusarium wilt diagnosis, while the molecular detection of $F$. oxysporum on other hosts has been reported $[24,25]$.

\section{Colletotrichum acutatum}

C. acutatum (Additional file 2: Table S5) is one of the most frequently reported species of the genus and causes anthracnose disease which is especially destructive on strawberry [26]. For rapid and specific assessment of the pathogen in strawberry, TaqMan rtPCR $[S \# 27,28]$ using primers designed to the rDNA ITS is used and strongly recommended. Development of the $b$-tubulin-based rtPCR primers is less complicated, but the single copy nature of this target leads to primers that are less sensitive and therefore less suitable for detection of C. acutatum than the multi-copy ITS regions [27]. In a similar study, Garrido et al. [28] demonstrated that TaqMan rtPCR is $10-100$ times more sensitive than cPCR [S\#29] for diagnosis of the strawberry anthracnose agent. Moreover, nPCR [S\#25] is another technique which can be successfully used to detect $C$. acutatum on symptomless strawberry leaves. Because of strong detection sensitivity, this method can be applied as a powerful tool for a reliable diagnosis of the pathogen in the field [29]. Since rtPCR is usually less affected by inhibitors such as chlorogenic acid than cPCR [30], detection of C. acutatum in necrotic leaf tissue may be more difficult with conventional or nested PCR than with rtPCR.

\section{Verticillium dahlia}

Verticillium wilt, caused by the soilborne fungus $V$. dahliae (Additional file 2: Table S6), is an economically important disease worldwide, which can cause significant crop loss on strawberry even with low soil inoculum densities [31,32]. Nested amplification [S\#30] assay and cPCR [S\#31], using modified DNA extraction methods for amplification improvement, are described as potential assays for detection of $V$. dahliae in the strawberry plant and soil. A multiplexed TaqMan rtPCR [S\#32] based on the rDNA IGS provides a more specific quantification of the pathogen at low inoculum densities with a higher level of sensitivity. According to Bilodeau et al. [33], the sensitivity of the method allows specific detection of one to two microsclerotia/g of $V$. dahliae in soil, which represents a higher sensitivity compared to other methods for this pathogen.

\section{Macrophomina phaseolina}

M. phaseolina (Tassi) Goid., the cause of charcoal rot on strawberry, has a wide geographic distribution because it infects the roots and lower stem of over 500 plant species [34,35]. Many PCR-based detection methods are able to detect $M$. phaseolina on plant tissues and soil [36-38], but no study has been found for detection and quantification of the pathogen on strawberry. However, published protocols may provide useful information about application of available detection methods on strawberry. Recently, a rtPCR using TaqMan and SYBR Green was published which enables a specific quantification of $M$. phaseolina abundance in rhizosphere and plant tissues [39]. Thus, this method seems to be a strong diagnostic tool for M. phaseolina.

\section{Discussion}

A variety of molecular methods have been described for specific detection and identification of phytopathogenic fungi and bacteria. However, the present compilation focused solely on the PCR-based protocols available for routine diagnosis including detection or quantification of strawberry pathogens. Our systematic review identified ten different protocols for $X$. fragariae, eight for $P$. fragariae, four for $B$. cinerea, six for C. acutatum, three for $V$. dahliae, and only one for F. oxysporum. No PCRbased detection method for M. phaseolina in strawberry could be identified in the literature yet. The strawberry pathogens included above were chosen due to their economic impact on crop losses, their distribution, and their status as quarantine organisms. Specificity and sensitivity of methods were identified by systematically summarizing the available literature (Additional file 2: Tables S1 to S6).

Generally, the sequences and the genomic targets of conserved universal genes with enough sequence variation between species are the best choice for designing PCR diagnostic assays. Depending on the genomic region chosen to design PCR primer sets, highly specific diagnostic tests can be obtained, allowing detection of the specific pathogen species and strains from related species or within the same species, respectively $[9,40]$. Primer design requires knowledge of the target DNA 
sequences, and multiple strategies are therefore being developed to design primers for specific detection and disease diagnosis [41-44]. The rDNA operon has frequently been used to design primers that allow highly sensitive detection, but due to its universal nature, the level of discrimination lies at the species levels [15]. The ITS region within prokaryotic and eukaryotic rDNA operons has been described as a stable genetic marker and was used to design primers by Bonants et al. [13,45], Vandroemme et al. [18], Turechek et al. [17], Kuchta et al. [46], Debode et al. [27], and Garrido et al. [28], among others. Thus, the ITS region is the most widely sequenced for strawberry pathogens. Another genomic portion of the rDNA cistron is the spacer between IGS or the non-transcribed spacer (NTS) that was used to design primers by Suarez et al. [21] and Bilodeau et al. [33]. IGS sequences are more difficult for amplification and sequencing, but they can be more variable than the ITS sequences. Thus, they are exploited to design diagnostic assays when there are not enough differences available across the ITS [9]. Moreover, among conserved genes, the $b$-tubulin has been used to develop diagnostic PCR assay for B. cinerea and C. acutatum. The sequence of this gene can be useful when the ITS sequence does not allow to fulfill specificity requirements of a diagnostic test [9]. A few loci suitable for the design of speciesspecific primers for $X$. fragariae have been identified: RAPD-specific regions $[47,48]$, within the $h r p[16,49,50]$ and $\operatorname{gyr} B[18,51]$ genes.

There is a discussion between results of studies that can be described by four variables. Firstly, in the primers reported here, sequences from pathogenicity-related genes of different species have been employed, although pathogenicity genes are not known in most cases. But, there is an example of the need to design new primers after the discovery of forma specialis that lack some pathogenicity genes, previously considered universal. Many types of transposable elements such as Hop, Hornet1, Foxy, Fofra, and Skippy were considered as excellent targets for $F$. oxysporum f.sp. fragariae detection, and several sets of primers were designed on its sequence [1,52-54]. However, the discovery of nonpathogenic $F$. oxysporum showed that these primers were not as specific as expected [1]. Secondly, the frequent presence of PCR inhibitors in the plant tissues or soil can considerably reduce the sensitivity of the reaction. Thus, a low copy number of initial target DNA sequences makes the first amplification cycles critical, because it may result in false-negative results caused by PCR inhibitors [14]. This could have a major impact on the result of diagnostic tests and therefore is a confounding, but important, variable. In this context, sample preparation is critical, and target DNA should be made as available as possible for amplification. So, an increasing number of commercial kits and DNA extraction protocols for DNA purification and removal of PCR inhibitors from plant materials and soils are available and reported in Additional file 2: Tables S1 to S6. Also, in two included studies [33,51], internal PCR controls were employed in order to improve sensitivity and avoid false negatives. Thirdly, some results were obtained from nucleic acids present in the soil rather than living cells. Hence, there is a risk of detecting target DNA from dead sources; DNA can persist in soil for long periods of time by forming complexes with soil components and may lead to positive PCR results [55,56]. Lastly, the majority of the included studies in the literature review investigated PCR methods based on agarose gels for detection/identification of strawberry pathogens. However, some studies focused on quantification of the pathogen using the rtPCR technique, in which sensitivity was increased. Conventional and real-time PCRs are difficult to compare because of the different throughput, sensitivity, and resolution levels [57].

Several methods have been developed to improve sensitivity of CPCR with regard to the goal of this study. Nested PCR with both internal and external primers to the target sequence was reported to increase detection sensitivity and reduce the effect of PCR inhibitors $[46,48,50]$. In fact, when the pathogen is present in very low levels, a higher level of specificity is needed, or the infestations need to be detected in complex environmental samples [50], affecting the reaction. However, the risk of false positives due to cross-contamination of reaction mixtures in routine analysis of large numbers of samples is increased by the introduction of a second round of amplification and the simultaneous manipulation of the previously amplified products [49]. To avoid these problems, nPCR in a single closed tube has been developed $[58,59]$.

mPCR, a PCR variant which is designed to amplify multiple targets by using multiple primer sets in the same reaction, was applied for detection of $F$. oxysporum in strawberry [1]. Although mPCR consists of a simultaneous screening method in a single reaction tube for the rapid and sensitive detection of different DNA targets, it requires a tedious and time-consuming optimization processes to keep up sensitivity of the single PCR due to competition between different amplification products in one tube [60]. Decrease in sensitivity and limited number of targets that can be simultaneously detected are the most significant drawbacks of mPCR [61]. rtPCR offers better multiplexing possibilities, but multiplexing is still limited by the availability of dyes emitting fluorescence at different wavelengths [14]. A similar limitation to the use of multiplex rtPCR is the competition between different primers and probes which can result in lower sensitivity and specificity [62,63]. However, Bilodeau et al. [33] 
reported a rapid and specific determination of soil inoculum densities of $V$. dahliae in strawberry fields without reduction of sensitivity against single amplifications using multiplexed TaqMan rtPCR. Another powerful and practical technique for simultaneous detection of multiple plant pathogens in a wide range of environmental samples is the macro- and micro-array $[8,64,65]$, but is not found for the aforementioned pathogens during our literature survey.

In plant disease management, the assumption that rtPCR is more sensitive than CPCR is widely accepted. The higher sensitivity of rtPCR compared to $\mathrm{CPCR}$ is determined by two main features: firstly, data are available in real time, are on-screen, do not require time-consuming post-PCR processing, and can be quantitative. Secondly, rtPCR assays commonly amplify very short DNA fragments (70-100 bp) which favors a higher level of PCR efficiency and sensitivity compared to cPCR $[28,66]$. In this regard, many different systems have been developed, including probe-based methods, such as TaqMan probes $[9,13,15]$ and molecular beacons [13]. In general, the protocols developed are based on hybridization of the probe to the target amplicon, thus achieving maximum sensitivity and confirming the identity of the amplified product $[14,15,28]$. Only 12 kinds of rtPCR protocols are referred to here for detection and quantification of strawberry pathogens. But one should bear in mind that their number has increased from only one in 2004 [13] to six between 2007 and $2012[17,18,27,28,33,51]$. It seems that, since amplicon detection through the specific fluorescent signal removes the requirements for post-amplification phases needed in $\mathrm{CPCR}$, it reduces time and considerably promotes the throughput of rtPCR assays, making it suitable for large-scale analyses of the mentioned pathogens. Besides, primers designed for $\mathrm{CPCR}$ can be utilized in rtPCR assays if amplicon size criteria are met [57]. Hence, existing $\mathrm{CPCR}$ protocols for the detection of plant pathogens can be adapted to be used in real-time detection (rtPCR assays), which can result in a higher level of sensitivity.

In this compilation, all of the rtPCR protocols have utilized probe-based methods, which provide greater sensitivity and specificity than other PCR techniques for detection of strawberry pathogens. However, DNA-intercalating dyes can offer a valid alternative to probe-based methods that bind to double-stranded DNA. SYBR Green is one of the most widely used intercalating DNA dyes for rtPCR applications because of cost efficiency, generic detection of amplified DNA, and its ability to differentiate PCR products by melting curve analysis [67]. Nevertheless, the drawback of using SYBR Green for melting curve analysis is that the melting temperature is highly dependent on the concentration of the dye [68] and DNA [69]. TaqMan ${ }^{\mathrm{TM}}$ and $\mathrm{SYBR}^{\mathrm{TM}}$ green techniques are most widely used for diagnostic purposes, but several considerations must be taken into account. First of all, the TaqMan technique tends to be more specific than SYBR Green due to the use of the sequence specific probe; however, this leads to higher initial costs [70]. Secondly, the SYBR Green method is cheaper to establish since fluorescent-labeled probes are not used; however, SYBR Green fluorophores can also associate with non-specific reaction products such as primer-dimers which may result in poor specificity and false-positive results [57]. Thirdly, availability of instrumentation, the degree of diversity among target and non-target sequences, and the need for multiplexing are primary factors in the choice of real-time platforms [70,71]. In fact, SYBR Green ${ }^{\text {mM }}$ does not allow to multiplex different amplification products. In this scenario, no SYBR Green protocol has been published for detection of studied strawberry pathogens yet. In this review, we also included studies using PCRELISA [13] and cPCR using PCR kit [16] that allow detection of $P$. fragariae and $X$. fragariae in strawberry plants, respectively. These techniques are not as powerful as rtPCR in detecting and quantifying pathogens but were nevertheless included in this review since they still did allow a reliable detection of strawberry pathogens.

\section{Limitations}

This review focuses mostly on sensitivity of PCR diagnostic methods outlined in the selected articles. Sensitivity of diagnostic methods is reported in Additional file 2: Tables S1 to S6; however, most studies did not include information on sensitivity levels of the investigated technique(s). Hence, accuracy of measurements based on their performance in pathogen detection was difficult to define because different studies employed different procedures for inoculum preparation, DNA extraction [72-74], and primer design (from different regions of the gene). These will impede to define common pre-analytical requirements, DNA isolation, and amplification procedure (as the factors that affect the efficiency of the test formats) to be employed in routine analyses with the aim of establishing a common diagnostic PCR-based method. Therefore, it was impossible to make direct comparisons between studies. Also, PCR-based quantification of genes amplified from nucleic acids isolated from environmental samples is influenced by a number of confounding factors. Firstly, nucleic acid extraction efficiencies are different between different methods, and so the performance of the final nucleic acid is dependent on both the method used and the type of environmental sample. Most included studies used commercial kits to extract DNA from strawberry tissues, because of their simplicity and rapidity together with the absence of harmful chemical compounds. However, DNA isolation kits can be expensive and inefficient when handling plants with high polyphenolic content. Secondly, many different extraction procedures are used for various samples and within different laboratories, 
making direct comparison between studies extremely problematic. Therefore, in order to compare detection sensitivity from different environmental samples, it must first be ensured that the same extraction procedure is used for each sample. Indeed, the absence of common preanalytical procedures might affect final results. Generally, real-time PCR was mostly used in the studies under investigations but not with the same primer and probe, resulting in a restricted comparability. However, while keeping the limitations of the used PCR-based methods in mind, rtPCR remains the gold standard technique for detection and quantification of strawberry pathogens.

\section{Conclusions}

From a systematic review of the currently available published literature, rtPCR is shown to be a particularly promising technique for diagnosing and quantifying pathogen populations in strawberry, whereas some other techniques are suitable for the identification/detection of the aforementioned pathogens. The technique rtPCR allows a specific, reliable, and high-throughput detection of target DNA in symptomless strawberry leaves and various environmental samples in real time. However, we hypothesize that a large proportion, possibly a majority, of errors in laboratories occurs in the pre-analytical phase of the testing process. Therefore, pre-analytical factors need to be considered when applying a diagnostic test. As more PCR-based methods for detection of plant pathogenic fungi and bacteria become available, their use will progressively increase not only for identification purposes but also for different applications, such as studies on pathogen population in their ecosystem in order to facilitate reliable detection. These studies are fundamental to obtain a comprehensive understanding of the pathogen biology with the final intent of optimizing plant disease management strategies.

\section{Additional files}

Additional file 1:Search strategy. The file contains a sample search strategy.

Additional file 2: Supporting information. Summaries of the included studies are reported along with the quantitative measurements undertaken by the original articles that assessed detection sensitivity in each protocol. Table S1: PCR-based techniques applied for detection of $X$. fragariae in strawberry. Table S2: PCR-based techniques applied for detection of $P$. fragariae in strawberry. Table S3: PCR-based techniques applied for detection of B. cinerea in strawberry. Table S4: PCR-based techniques applied for detection of F. oxysporum f.sp. fragariae in strawberry. Table S5 PCR-based techniques applied for detection of C. acutatum in strawberry. Table S6: PCR-based techniques applied for detection of $V$. dahliae in strawberry.

\section{Competing interests}

The authors declare that they have no competing interests.

\section{Authors' contributions}

SMM conceptualized and designed the study and conducted the search strategy, drafted the initial manuscript, and approved the final manuscript as submitted. EL supervised the search strategy and the methods, critically reviewed and revised the manuscript, and approved the final manuscript as submitted. MM contributed to the concept and design of the study, reviewed the manuscript, and approved the final manuscript as submitted. MD and RAG critically reviewed and revised the manuscript and approved the final manuscript as submitted. All authors read and approved the final manuscript.

\section{Acknowledgements}

This work was funded by EUPHRESCO (European Phytosanitary Research Coordination) Phytosanitary ERA-Net project SPAT (Strawberry Pathogens Assessment and Testing). The authors especially thank Prof. Peter Harley (National Center for Atmospheric Research, Colorado, USA) for his critical reviewing of the manuscript. We also thank Inmaculada Larena (Agricultural National Research Institute, Department of Plant Protection, Madrid, Spain) and Maria Bergsma-Vlami (National Reference Centre, Plant Protection Service, Wageningen, The Netherlands) for giving valuable comments and suggestions for improving the quality of this work.

\section{Author details}

${ }^{1}$ Department of Field Crops and Grassland Husbandry, Institute of Agricultural and Environmental Sciences, Estonian University of Life Sciences, Tartu, Estonia. ${ }^{2}$ Pesticides, Plant Health and Seed Testing Laboratories, Department of Agriculture, Food and the Marine, Backweston Campus, Celbridge, Co. Kildare, Ireland. ${ }^{3}$ Department for Molecular Diagnostics of Plant Diseases, Institute for Sustainable Plant Production, Austrian Agency for Health and Food Safety (AGES), Vienna, Austria. ${ }^{4}$ Department of Plant Protection, Institute of Agricultural and Environmental Sciences, Estonian University of Life Sciences, Tartu, Estonia.

Received: 8 July 2014 Accepted: 2 January 2015

Published: 15 January 2015

\section{References}

1. Suga H, Hirayama Y, Suzuki T, Kageyama K, Hyakumachi M. Development of PCR primers to identify Fusarium oxysporum f. sp. fragariae. Plant Dis. 2013;97(5):619-25

2. Faostat (Food and Agriculture Organization Corporate Statistical Database). World strawberry production. 2013. [http://faostat.fao.org/site/567/ DesktopDefault.aspx?PagelD = 567\#ancor. Accessed 9 Mar 2013.

3. Maas JL. Compendium of strawberry diseases. St Paul, MN: APS Press; 1998.

4. Redondo C, De-Cal A, Martinez-Treceño A, Becerril M, López-Aranda JM, Melgarejo P. Evaluation of resistance of several strawberry selections against main fungal pathogens. In: López-Medina J, editor. Proceedings of the VI International Strawberry Symposium: 3-7 March 2009; Huelva (Spain). Acta Horticulturae 842. 2009. p. 211-4.

5. Sankarana S, Mishraa A, Ehsania R, Davis C. A review of advanced techniques for detecting plant diseases. Comput Electron Agr. 2010;72:1-13.

6. McCartney HA, Foster SJ, Fraaije BA, Ward E. Molecular diagnostics for fungal plant pathogens. Pest Manag Sci. 2003;59:129-42.

7. Singleton LL, Mihail JD, Rush CM. Methods for research on soil-borne phytopathogenic fungi. St Paul, MN: APS Press; 1992.

8. Lievens B, Brouwer M, Vanachter ACRC, Levesque CA, Cammue BPA, Thomma BPHJ. Quantitative assessment of phytopathogenic fungi in various substrates using a DNA macroarray. Environ Microbiol. 2005:7(11):1698-710.

9. Schena L, Nigro F, Ippolito A. Real-time PCR detection and quantification of soilborne fungal pathogens: the case of Rosellinia necatrix, Phytophthora nicotianae, P. citrophthora, and Verticillium dahliae. Phytopathol Mediterr. 2004:43:273-80.

10. Lievens B, Grauwet TJMA, Thomma CBPA, BPHJ. Recent developments in diagnostics of plant pathogens: a review. Recent Res Develop Microbiol. 2005:9:57-79.

11. OEPP/EPPO (European and Mediterranean Plant Protection Organization) Diagnostics; Xanthomonas fragariae. Bull OEPP/EPPO. 2006;36:135-44

12. López MM, Llop P, Olmos A, Marco-Noales E, Cambra M, Bertolini E. Are molecular tools solving the challenge posed by detection of plant pathogenic bacteria and viruses? Curr Issues Mol Biol. 2009;11:13-46. 
13. Bonants P, van Gent-Pelzer MPE, Hooftman R, Cooke D, Guy DC, Duncan JM. A combination of baiting and different PCR formats, including measurement of real-time quantitative fluorescence, for the detection of Phytophthora fragariae in strawberry plants. Eur J Plant Pathol. 2004;110:689-702.

14. Schena L, Li Destri Nicosia MG, Sanzani SM, Faedda R, Ippolito A, Cacciola SO. Development of quantitative PCR detection methods for phytopathogenic fungi and oomycets. J Plant Pathol. 2013;95(1):7-24.

15. Schaad NW, Frederick RD, Shaw J, Schneider WL, Hickson R, Petrillo MD, et al. Advances in molecular-based diagnostics in meeting crop biosecurity and phytosanitary issues. Annu Rev Phytopathol. 2003;41:305-24.

16. Stöger A, Ruppitsch W. A rapid and sensitive method for the detection of Xanthomonas fragariae, causal agent of angular leafspot disease in strawberry plants. J Microbiol Meth. 2004;58:281-4

17. Turechek WW, Hartung JS, McCallister J. Development and optimization of a real-time detection assay for Xanthomonas fragariae in strawberry crown tissue with receiver operating characteristic curve analysis. Phytopathol. 2008;98(3):359-68.

18. Vandroemme J, Baeyen S, Van Vaerenbergh J, De Vos P, Maes M. Sensitive real-time PCR detection of Xanthomonas fragariae in strawberry plants. Plant Pathol. 2008;57:438-44.

19. loos R, Laugustin L, Schenck N, Rose S, Husson C, Frey P. Usefulness of single copy genes containing introns in Phytophthora for the development of detection tools for the regulated species $P$. ramorum and $P$. fragariae. Eur J Plant Pathol. 2006;116:171-6.

20. Guinebretiere $\mathrm{MH}$, Morrison C, Reich M, Nicot P. Isolation and characterization of antagonists for the biocontrol of the postharvest wound pathogen Botrytis cinerea on strawberry fruits. J Food Protect. 2000;63:386-94.

21. Suarez MB, Walsh K, Boonham N, O'Neill T, Pearson S, Barker I. Development of real-time PCR (TaqMan ${ }^{\oplus}$ ) assays for the detection and quantification of Botrytis cinerea in planta. Plant Physiol Bioch. 2005:43:890-9.

22. Rigotti S, Gindro K, Richter H, Viret O. Characterization of molecular markers for specific and sensitive detection of Botrytis cinerea Pers.: Fr. in strawberry (Fragaria $\times$ ananassa Duch.) using PCR. FEMS Microbiol Lett. 2002;209:169-74.

23. Arroyo FT, Llergo Y, Aguado A, Romero F. First report of fusarium wilt caused by Fusarium oxysporum on strawberry in Spain. Plant Dis. 2009:93:323-3.

24. Abd-Elsalam KA, Asran-Amal A, Schnieder F, Migheli Q, Verreet JA. Molecular detection of Fusarium oxysporum f. sp. vasinfectum in cotton roots by PCR and real-time PCR assay. J Plant Dis Protect. 2006;113(1):14-9.

25. Li Y, Garibaldi A, Gullino ML. Molecular detection of Fusarium oxysporum f. sp. chrysanthemi on three host plants: Gerbera jamesonii, Osteospermum sp. and Argyranthemum frutescens. J. Plant Pathol. 2010;92(2):525-30.

26. Damm U, Cannon PF, Woudenberg JHC, Crous PW. The Colletotrichum acutatum species complex. Stud Mycol. 2012;73:37-113.

27. Debode J, Van Hemelrijck W, Baeyen S, Creemers P, Heungens K, Maes M. Quantitative detection and monitoring of Colletotrichum acutatum in strawberry leaves using real-time PCR. Plant Pathol. 2009:58:504-14.

28. Garrido C, Carbú M, Fernández-Acero FJ, Boonham N, Colyer A, Cantoral JM, et al. Development of protocols for detection of Colletotrichum acutatum and monitoring of strawberry anthracnose using real-time PCR. Plant Pathol. 2009:58:43-51.

29. Pérez-Hernández O, Nam MH, Gleason ML, Kim HG. Development of a nested polymerase chain reaction assay for detection of Colletotrichum acutatum on symptomless strawberry leaves. Plant Dis. 2008;92(12):1655-61.

30. Mumford RA, Walsh K, Barker I, Boonham N. Detection of potato mop top virus and tobacco rattle virus using a multiplex real-time fluorescent reverse transcription polymerase chain reaction assay. Phytopathol. 2000;90:448-53.

31. Bhat RG, Subbarao KV. Host range specificity in Verticillium dahliae. Phytopathol. 1999;89:1218-25.

32. Pegg B, Brady G. Verticillium wilts. New York: CABI Publishing; 2002.

33. Bilodeau GJ, Koike ST, Uribe P, Martin FN. Development of an assay for rapid detection and quantification of Verticillium dahliae in soil. Phytopathol. 2012;102(3):331-43.

34. Mihail JD, Taylor SJ. Interpreting variability among isolates of Macrophomina phaseolina in pathogenicity, pycnidium production and chlorate utilization. Can J Bot. 1995;10:1596-603.

35. Su G, Suh SO, Schneider RW, Russin JS. Host specialization in the charcoal rot fungus, Macrophomina phaseolina. Phytopathol. 2001;91:120-6.

36. Babu BK, Saxena AK, Srivastava AK, Arora DK. Identification and detection of Macrophomina phaseolina by using species specific oligonucleotide primers and probe. Mycologia. 2007;99(6):797-803.
37. Chakraborty BN, Chakraborty U, Dey PL, Rai K. rDNA sequence and phylogenetic analysis of Macrophomina phaseolina, root rot pathogen of Citrus reticulata (Blanco). Global J Mol Sci. 2011;6:26-34.

38. Almomani F, Alhawatema M, Hameed K. Detection, identification and morphological characteristic of Macrophomina phaseolina: the charcoal rot disease pathogens isolated from infected plants in Northern Jordan. Arch Phytopathol Plant Protect. 2013;46(9):1005-14.

39. Babu BK, Mesapogu S, Sharma A, Somasani SR, Arora DK. Quantitative realtime PCR assay for rapid detection of plant and human pathogenic Macrophomina phaseolina from field and environmental samples. Mycologia. 2011;103(3):466-73.

40. Henson JM, French R. The polymerase chain reaction and plant disease diagnosis. Annu Rev Phytopathol. 1993;31:81-109.

41. Williams JGK, Kubelik AR, Livak KJ, Rafalski JA, Tingey SV. DNA polymorphisms amplified by arbitrary primers are useful as genetic markers. Nucleic Acids Res. 1990;18:6531-5.

42. Fraaije BA, Lovell DJ, Coelho JM, Baldwin S, Hollomon DW. PCR-based assays to assess wheat varietal resistance to blotch (Septoria tritici and Stagonospora nodorum) and rust (Puccinia striiformis and Puccinia recondita) diseases. Eur J Plant Pathol. 2001;107:905-17.

43. Schmittgen TD. Real-time quantitative PCR. Methods. 2001;25:383-5.

44. Lees AK, Cullen DW, Sullivan L, Nicolson MJ. Development of conventional and quantitative real-time PCR assays for the detection and identification of Rhizoctonia solani AG-3 in potato and soil. Plant Pathol. 2002;51:293-302.

45. Bonants P, Weerdt MH, van Gent-Pelzer M, Lacourt I, Cooke D, Duncan J. Detection and identification of Phytophthora fragariae Hickman by the polymerase chain reaction. Eur J Plant Pathol. 1997;103:345-55.

46. Kuchta P, Jecz T, Korbin M. The suitability of PCR-based techniques for detecting Verticillium dahliae in strawberry plants and soil. J Fruit Ornamental Plant Res. 2008;16:295-304.

47. Pooler MR, Ritchie DF, Hartung JS. Genetic relationships among strains of Xanthomonas fragariae based on random amplified polymorphic DNA PCR, repetitive extragenic palindromic $P C R$, and enterobacterial repetitive intergenic consensus PCR data and generation of multiplexed PCR primers useful for the identification of this phytopathogen. Appl Environ Microbiol. 1996;62(9):3121-7.

48. Zimmermann C, Hinrichs-Berger J, Moltmann E, Buchenauer H. Nested PCR (polymerase chain reaction) for detection of Xanthomonas fragariae in symptomless strawberry plants. J Plant Dis Protect. 2004;111(1):39-51.

49. Roberts PD, Jones JB, Chandler CK, Stall RE, Roberts PD, Jones JB, et al. Survival of $X$. fragariae on strawberry in summer nurseries in Florida detected by specific primers and nested PCR. Plant Dis. 1996;80(11):1283-8.

50. Mahuku GS, Goodwin PH. Presence of Xanthomonas fragariae in symptomless strawberry crowns in Ontario detected using a nested polymerase chain reaction (PCR). Can J Plant Pathol. 1997;19(4):366-70.

51. Weller SA, Beresford-Jones NJ, Hall J, Thwaites R, Parkinson N, Elphinstone JG. Detection of Xanthomonas fragariae and presumptive detection of Xanthomonas arboricola pv. fragariae, from strawberry leaves, by real-time PCR. J Microbiol Methods. 2007;70:379-83.

52. Hua-Van A, Daviere JM, Kaper F, Langin T, Daboussi MJ. Genome organization in Fusarium oxysporum: clusters of class II transposons. Curr Genet. 2000;37:339-47.

53. Anaya N, Roncero MIG. Skippy, a retrotransposon from the fungal plant pathogen Fusarium oxysporum. Mol Gen Genet. 1995;249:637-47.

54. Chalvet F, Grimaldi C, Kaper F, Langin T, Daboussi MJ. Hop, an active mutator-like element in the genome of the fungus Fusarium oxysporum. Mol Biol Evol. 2003;20:1362-75.

55. England LS, Lee H, Trevors JT. Persistence of Pseudomonas aureofaciens strains and DNA in soil. Soil Biol Biochem. 1997;29:1521-7.

56. Wolffs P, Norling B, Rådström P. Risk assessment of false-positive quantitative real-time PCR results in food, due to detection of DNA originating from dead cells. J Microbiol Methods. 2005;60:315-23.

57. Okubara PA, Schroeder KL, Paulitz TC. Real-time polymerase chain reaction: applications to studies on soil borne pathogens. Can J Plant Pathol. 2005;27:300-13.

58. Mercado-Blanco J, Rodríguez-Jurado D, Pérez-Artés E, Jiménez-Díaz RM. Detection of the nondefoliating pathotype of Verticillium dahliae in infected olive plants by nested PCR. Plant Pathol. 2001;50(5):609-19.

59. Grote D, Olmos A, Kofoet JJ, Tuset E, Bertolini E, Cambra M. Specific and sensitive detection of Phytophthora nicotianae by simple and nested-PCR. Eur J Plant Pathol. 2002;108(3):197-207. 
60. Elnifro EM, Ashishi AM, Cooper RJ, Klapper PE, Multiplex PCR. Optimization and application in diagnostic virology. Clin Microbiol Rev. 2000;13:559-70.

61. Bamaga MS, Wright DJ, Zhang H. An assessment of multiplex PCR assays for differentiating clinically important mycobacteria based on pncA gene variation. Mol Cell Probes. 2003;17:69-75.

62. Tooley PW, Martin FN, Carras MM, Frederick RD. Real-time fluorescent polymerase chain reaction detection of Phytophthora ramorum and Phytophthora pseudosyringae using mitochondrial gene regions. Phytopathol. 2006;96:336-45.

63. Scauflaire J, Godet M, Gourgue M, Liénard C, Munaut F. A multiplex realtime PCR method using hybridization probes for the detection and the quantification of Fusarium proliferatum, F. subglutinans, F. temperatum, and F. verticillioides. Fungal Biol. 2012;10:1073-80.

64. Chen W, Seifert KA, Lévesque CA. A high density COX1 barcode oligonucleotide array for identification and detection of species of Penicillium subgenus Penicillium. Mol Ecol Resour. 2009;9:114-29.

65. Call DR. Challenges and opportunities for pathogen detection using DNA microarrays. Crit Rev Microbiol. 2005;31:91-9.

66. Garrido C, Carbú M, Fernández-Acero FJ, González-Rodríguez VE, Cantoral $J M$. New insight in the study of strawberry fungal pathogens. Genes Genomes Genomics. 2011;5(1):24-39.

67. Morrison TB, Weis JJ, Wittwer CT. Quantification of low-copy transcripts by continuous SYBR Green I monitoring during amplification. Biotechniques. 1998:24:954-8

68. Ririe KM, Rasmussen RP, Wittwer CT. Product differentiation by analysis of DNA melting curves during the polymerase chain reaction. Anal Biochem. 1997;245:154-60.

69. Xu HX, Kawamura Y, Li N, Zhao LC, Li TM, Li ZY, et al. A rapid method for determining the $\mathrm{G}+\mathrm{C}$ content of bacterial chromosomes by monitoring fluorescence intensity during DNA denaturation in a capillary tube. Int J Syst Evol Micr. 2000;50:1463-9.

70. Wittwer CT, Herrmann MG, Moss AA, Rasmussen RP. Continuous fluorescence monitoring of rapid cycle DNA amplification. Biotechniques. 1997;22(1):130-8

71. Whitcombe D, Theaker J, Guy SP, Brown T, Little S. Detection of PCR products using self-probing amplicons and fluorescence. Nat Biotechnol. 1999;17:804-7.

72. Drenth A, Wagels G, Smith B, Sendall B, O'Dwyer C, Irvine G, et al. Development of a DNA-based method for detection and identification of Phytophthora species. Australas Plant Path. 2006;35:147-59.

73. Sreenivasaprasad S, Sharada K, Brown AE, Mills PR. PCR-based detection of Colletotrichum acutatum on strawberry. Plant Pathol. 1996;45(4):650-5.

74. Zhang S, Goodwin PH. Rapid and sensitive detection of Xanthomonas fragariae by simple alkaline DNA extraction and the polymerase chain reaction. J Phytopathol. 1997;145(5-6):267-70.

doi:10.1186/2046-4053-4-9

Cite this article as: Mirmajlessi et al.: PCR-based specific techniques used for detecting the most important pathogens on strawberry:

a systematic review. Systematic Reviews 2015 4:9.

\section{Submit your next manuscript to BioMed Central and take full advantage of:}

- Convenient online submission

- Thorough peer review

- No space constraints or color figure charges

- Immediate publication on acceptance

- Inclusion in PubMed, CAS, Scopus and Google Scholar

- Research which is freely available for redistribution 